ISSN 1392-3196 / e-ISSN 2335-8947

Zemdirbyste-Agriculture, vol. 108, No. 1 (2021), p. 63-70

DOI 10.13080/z-a.2021.108.009

\title{
Qualitative and quantitative composition of triterpenic compounds in the fruit of apple old cultivars grown in Lithuania
}

\author{
Aurita BUTKEVIČIŪTĖ ${ }^{1}$, Mindaugas LIAUDANSKAS ${ }^{1,2}$, Darius KVIKLYS ${ }^{2,3}$, \\ Dalia GELVONAUSKIENE ${ }^{2}$, Valdimaras JANULIS ${ }^{1}$ \\ ${ }^{1}$ Lithuanian University of Health Sciences, Medical Academy \\ Sukilèlių 13, Kaunas, Lithuania \\ E-mail: aurita.butkeviciute@1smu.lt \\ ${ }^{2}$ Lithuanian Research Centre for Agriculture and Forestry \\ Kauno 30, Babtai, Kaunas distr., Lithuania \\ ${ }^{3}$ Norwegian Institute of Bioeconomy Research - NIBIO Ullensvang \\ Lofthus, Norway
}

\begin{abstract}
The interest in old cultivars of apple trees, their fruit and processed products is growing worldwide. Studies on the qualitative and quantitative composition of biological compounds are important for the evaluation of the quality and nutritional properties of apple fruit. A variation in the qualitative and quantitative composition of triterpenic compounds was found in the fruit of apple cultivars included in the collection of National Plant Genetic Resources. A high-performance liquid chromatography (HPLC) analysis showed that the fruit of the cultivar 'Birutès pepinas' had the highest total amount $\left(5.17 \pm 0.86 \mathrm{mg} \mathrm{g}^{-1}\right)$ of triterpenic compounds. Higher total amounts of triterpenic compounds were also found in the fruit of apple cultivars 'Tabokine' and 'Panemunès baltasis' (3.72 \pm 0.57 and $4.25 \pm 0.17 \mathrm{mg} \mathrm{g}^{-1}$, respectively). By the quantitative composition, triterpenic compounds in apple fruit were ranked in the following order: ursolic acid $>$ oleanolic acid $>$ corosolic acid $>$ betulinic acid.

The old apple cultivars 'Birutès pepinas', 'Panemunés baltasis' and 'Tabokiné' included in the collection of National Plant Genetic Resources have a potential for cultivation in industrial orchards and for the use of their apples, and processed apple products as natural functional foods rich in triterpenic compounds and adapted for medical purposes, including the prevention of various diseases.
\end{abstract}

Key words: apple, old cultivars, triterpenic compounds.

\section{Introduction}

Plants of the apple (Malus Mill.) genus are most common in moderate climate zones of Central Asia, Europe and Northern America (De Paepe et al., 2015). Domesticated apple trees (Malus domestica Borkh.) have been grown worldwide for at least 4000 years. The first written data on Lithuanian orchards, where apple trees were grown date back to 1387 (Kviklys et al., 2020). Part of the apple cultivars grown in Lithuania are thought to have been selected from naturally growing forest apple tree (Malus sylvestris (L.) Mill.) saplings (Blažyte, 2008; Biviliené et al., 2010). Scientific data suggest that the old cultivars are more resistant to winter cold, fungal infections and other pathogenic conditions, are more adapted to the local climatic conditions and ripen fruit within a short vegetation period (Contessa, Botta, 2016). Apples of the old historically grown cultivars are nutritious and of high quality (Lo Piccolo et al., 2019), and they accumulate higher phenolic and triterpenic compounds compared to apple fruit of the cultivars grown in industrial orchards (Grigoras et al., 2013; Padua et al., 2014). Studies have shown that the amount of triterpenic compounds in the apples of the old cultivars is twice that found in the fruit of apple trees grown in industrial orchards (Lo Piccolo et al., 2019; Sut et al., 2019). The triterpenic acids (ursolic, oleanolic, corosolic and betulinic) detected in apple fruit are characterized by versatile biological effects, i.e. they reduce blood levels of low density lipoprotein cholesterol and glucose, suppress atherosclerotic plaque formation and inflammatory processes and have an antineoplastic, antibacterial and antiviral effect (Allouche et al., 2010; Jeong et al., 2015; Waldbauer et al., 2016).

The last decades have seen a highly intensive development of commercial horticulture (Kviklys et al., 2020). The apple cultivars grown in the USA industrial orchards: 'Golden Delicious', 'Delicious', 'Cox's Orange Pippin', 'Rome Beauty', 'Granny Smith', 'McIntosh',

Please use the following format when citing the article:

Butkevičiūtė A., Liaudanskas M., Kviklys D., Gelvonauskienė D., Janulis V. 2021. Qualitative and quantitative composition of triterpenic compounds in the fruit of apple old cultivars grown in Lithuania. Zemdirbyste-Agriculture, 108 (1): 63-70. DOI 10.13080/z-a.2021.108.009 
'Jonathan', 'Braeburn', 'Fuji', 'Gala' and 'Jonagold', have replaced the old ones (De Paepe et al., 2015). According to the data of the study, of the 7098 apple cultivars cultivated between 1804 and 1904 in the USA, approximately $86 \%$ has been lost. In Europe, there still remains the heritage of the genetic resources of the old fruit-trees consisting of cultivars grown in private orchards.

As the interest in old cultivars of apple trees, their fruit and processed products is growing worldwide, studies of the qualitative and quantitative composition of biological compounds are important for the evaluation of the quality and nutritional properties of the apples. A search of scientific literature did not yield any studies on the composition of the active compounds in the fruit of old apple tree cultivars grown in Lithuania. Studies on the variations in the chemical composition of triterpenic compounds characterized by a versatile biological effect are important, when researching the genetic heritage of the old cultivars in order to increase the cultivation of such cultivars in orchards. The data of such studies will provide new scientifically important knowledge about the variations in the qualitative and quantitative chemical composition of biologically active compounds in apple fruit of the old cultivars. Target-oriented detailed studies of the phytochemical composition of triterpenic compounds will serve as a basis for the recommendation of the apple tree cultivars that would be most suitable for Lithuanian climatic conditions. Due to the content of biologically active compounds, apples of the old cultivars may be rationally used for food as well as for the manufacturing of high-quality food products. The data of such studies will provide new scientifically important knowledge about the variations in the qualitative and quantitative chemical composition of biologically active compounds in apple fruit of the old cultivars.

The aim of the study was to evaluate the variations in the qualitative and quantitative composition of triterpenic compounds in the apple fruit of the old apple cultivars grown in Lithuania.

\section{Materials and methods}

The experiment included 22 old apple cultivars, of which 21 (except for 'Golden Russet') are included in the collection of the National Plant Genetic Resources (Table).

The apple trees were grown in the Collection of the Apple Tree Genetic Resources at the Institute of Horticulture $\left(55^{\circ} 60^{\prime} \mathrm{N}, 23^{\circ} 48^{\prime} \mathrm{E}\right)$, a division of the Lithuanian Research Centre for Agriculture and Forestry. The research was conducted in 2019 and 2020.

Chemicals. All solvents, reagents and standards used were of analytical grade. Acetonitrile, acetone, ursolic acid, oleanolic acid, betulinic acid and corosolic acid were obtained from Sigma-Aldrich $\mathrm{GmbH}$ (Switzerland). Purified deionized water used in the tests was prepared with the Milli-Q ${ }^{\circledR}$ (Millipore, USA) water purification system.

Table. Origin and properties of the old apple cultivars of Lithuania

\begin{tabular}{|c|c|c|c|c|c|}
\hline Cultivar & $\begin{array}{l}\text { Year of introduction, discovery } \\
\text { or description, country }\end{array}$ & $\begin{array}{l}\text { Summer } \\
\text { cultivar }\end{array}$ & $\begin{array}{l}\text { Autumn } \\
\text { cultivar }\end{array}$ & $\begin{array}{l}\text { Winter } \\
\text { cultivar }\end{array}$ & Other exclusive properties \\
\hline Avenarijus & 1886, Russia & + & - & - & $\begin{array}{l}\text { sweet; flesh pink under the skin; } \\
\text { susceptible to canker }\end{array}$ \\
\hline Baltasis alyvinis & 1848, Russia & + & - & - & $\begin{array}{l}\text { white flesh, yellow skin; aromatic; } \\
\text { susceptible to scab }\end{array}$ \\
\hline Beržininkų ananasinis & 1886, Lithuania & - & + & - & $\begin{array}{l}\text { crispy flesh, yellow skin; aromatic; } \\
\text { scab-resistant }\end{array}$ \\
\hline Birutès pepinas & 1941, Lithuania & - & + & - & $\begin{array}{l}\text { white flesh, with suspicion of wine; } \\
\text { susceptible to scab }\end{array}$ \\
\hline Biržuvėnų žieminis & Lithuania & - & - & + & $\begin{array}{l}\text { sweet; yellow skin; } \\
\text { scab-resistant }\end{array}$ \\
\hline Danų karalienė Luiza & 1878, Denmark & - & - & + & $\begin{array}{l}\text { creamy yellow flesh, skin covered with } \\
\text { a rust grid; scab-resistant }\end{array}$ \\
\hline Geltonasis arkadas & $19^{\text {th }}$ century, Russia & + & - & - & $\begin{array}{l}\text { sweet, sometimes astringent; } \\
\text { susceptible to scab }\end{array}$ \\
\hline Golden Russet & 1800-1849, USA & - & - & + & $\begin{array}{l}\text { strong russet skin, creamy yellow flesh; } \\
\text { scab-resistant }\end{array}$ \\
\hline Jono pepinas & $19^{\text {th }}$ century, Lithuania & - & - & + & $\begin{array}{l}\text { firm, yellow flesh; } \\
\text { scab-resistant }\end{array}$ \\
\hline Koštelè & $19^{\text {th }}$ century, Poland & - & + & - & $\begin{array}{l}\text { sweet; firm and creamy flesh; } \\
\text { scab-resistant }\end{array}$ \\
\hline Lietuvos pepinas & $18^{\text {th }}$ century, Lithuania & - & - & + & $\begin{array}{l}\text { vinous taste, white flesh; } \\
\text { susceptible to scab }\end{array}$ \\
\hline Montvilinis & 1879, Lithuania & - & - & + & aromatic; scab-resistant \\
\hline Paprastasis antaninis & $18^{\text {th }}$ century, Russia & - & + & - & $\begin{array}{l}\text { acidic, very aromatic; } \\
\text { moderately scab-resistant }\end{array}$ \\
\hline Panemunès baltasis & 1939, Lithuania & - & + & - & $\begin{array}{l}\text { white flesh, greenish-yellow and waxed } \\
\text { skin; scab-resistant }\end{array}$ \\
\hline Pilkasis alyvinis & 1653, Russia & + & - & - & white flesh; susceptible to scab \\
\hline Popierinis & $\sim 1852$, Lithuania or Latvia & + & - & - & $\begin{array}{l}\text { white-yellow skin, white flesh; } \\
\text { susceptible to scab }\end{array}$ \\
\hline Raudonasis alyvinis & $18^{\text {th }}$ century, Russia & + & - & - & aromatic, susceptible to scab \\
\hline Rudens dryžuotasis & $\sim 1870$, Baltic countries & - & + & - & $\begin{array}{l}\text { vinous taste, aromatic; flesh pinkish } \\
\text { under skin; moderately scab-resistant }\end{array}$ \\
\hline Sierinka & $\sim 1860$, Baltic countries & - & + & - & $\begin{array}{l}\text { fragrant with characteristic aroma; } \\
\text { susceptible to canker, } \\
\text { moderately scab-resistant }\end{array}$ \\
\hline Tabokinè & $19^{\text {th }}$ century, Baltic countries & - & - & + & $\begin{array}{l}\text { bitter-sweet, bitterness weakens by } \\
\text { spring; scab-resistant }\end{array}$ \\
\hline Virginijos rožinis & 1816, Europe & + & - & - & vinous taste; susceptible to scab \\
\hline Žemaičių grietininis & $19^{\text {th }}$ century, Lithuania or Latvia & + & - & - & white flesh; moderately scab-resistant \\
\hline
\end{tabular}


Preparation of samples. For the analysis, 20 apples were picked from different parts of the tree crown at the optimal maturity stage. Whole apples were immediately frozen in a freezer (at $-35^{\circ} \mathrm{C}$ temperature) with air circulation. Subsequently, the frozen samples were lyophilised with a ZIRBUS sublimator $3 \times 4 \times 5 / 20$ (ZIRBUS technology $\mathrm{GmbH}$, Germany) at a pressure of $0.01 \mathrm{mbar}$ (condenser temperature $-85^{\circ} \mathrm{C}$ ). The lyophilised samples were ground to fine powder by using a mill electric grinder Retsch 200 (Germany). Loss on drying before the analysis was determined by drying the apple lyophilisate in a laboratory drying oven to complete the evaporation of water and volatile compounds (at $105^{\circ} \mathrm{C}$ temperature; the difference in weight between measurements up to $0.01 \mathrm{~g}$ ) and by calculating the difference in raw material weight before and after drying. The data were recalculated for the absolute dry lyophilisate weight. The prepared apple samples were stored in dark, tightly closed glass vessels.

Extraction. During the analysis, $1 \mathrm{~g}$ of lyophilisate powder (exact weight) was weighed, added to $10 \mathrm{~mL}$ of acetone and extracted in a ultrasonic bath Sonorex Digital 10 P (Bandelin Electronic GmbH \& Co. $\mathrm{KG}$, Germany) at a room temperature for $10 \mathrm{~min}$. The conditions of the extraction were chosen based on the results of the tests for setting the extraction conditions. The obtained extract was filtered through a paper filter, and the residue on the filter was washed with acetone in a $10 \mathrm{~mL}$ flask until the exact volume was reached.

$$
\text { Instrumentation and chromatographic }
$$

conditions. A chromatograph equipped with a photodiode array (PDA) detector Waters 2998 (Waters, USA) was used for high-performance liquid chromatography (HPLC) analysis. Chromatographic separations were carried out by using an ACE (advanced column engineering) column, $5 \mu \mathrm{m}, \mathrm{C} 18,250 \times 4.6 \mathrm{~mm}$ inner diameter. The column was operated at a constant temperature of $25^{\circ} \mathrm{C}$ The volume of the analysed extract was $10 \mu \mathrm{L}$. The flow rate was $1 \mathrm{~mL} \mathrm{~min}^{-1}$. The mobile phase consisted of acetonitrile (solvent $\mathrm{A}$ ) and water (solvent $\mathrm{B}$ ); the isocratic elution, the eluent ratio being $88 \%$ (solvent $\mathrm{A}$ ) and $12 \%$ (solvent B) was applied. For the quantitative analysis, the calibration curve was obtained by injecting the known concentrations of different standard compounds. All the identified triterpenic compounds were quantified at 205 nm wavelength (Butkevičiūtè et al., 2018).

Statistical analysis of the experimental data was performed by using software Microsoft Office Excel (Microsoft, USA) and SPSS, version 25.0 (SPSS Inc., USA). All the results obtained during the HPLC analysis were presented as means of three consecutive test results and standard deviations. To evaluate the variance in the quantitative composition, the coefficient of variation was calculated. Univariate analysis of variance (ANOVA) was applied to determine, whether the differences between the compared data were statistically significant. The hypothesis about the equality of variances was verified by Levine's test. If the variances of independent variables were found to be equal, Tukey's multiple comparison test was used. The differences were regarded as statistically significant at $p<0.05$. The comparison of the chemical composition between the apple samples was carried out by applying the hierarchical cluster analysis using the squared Euclidean distance. Principal component analysis (PCA) was performed as well.

\section{Results and discussion}

The conducted research determined the variation in the qualitative and quantitative composition of triterpenic compounds in fruit samples of the old apple cultivars grown in Lithuania. In apple fruit, the following triterpenic compounds were detected and qualitatively evaluated: betulinic acid, corosolic acid, oleanolic acid and ursolic acid; retention times of these acids were 6.03, 8.71, 9.92 and $10.40 \mathrm{~min}$, respectively (Fig. 1).

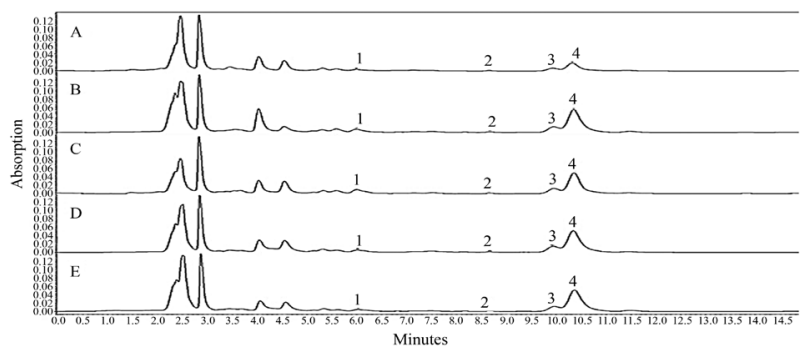

A - 'Danu karalienė Luiza', B - 'Panemunès baltasis', C 'Paprastasis antaninis', D - 'Rudens dryžuotasis', E - 'Žemaičiu grietininis'; analytes: 1 - corosolic acid, 2 - betulinic acid, 3 - oleanolic acid, 4 - ursolic acid

Figure 1. HPLC chromatograms of fruit of the old apple cultivars

Apple extracts are multi-component matrices of chemical compounds with complex structures, and they vary in the chemical composition (Contessa, Botta, 2016). In order to provide the consumers with high-quality apples and apple products with known chemical composition, the evaluation of the variations in the quantitative composition of triterpenic compounds is relevant.

The amount of ursolic acid in apple fruit ranged from 0.20 to $4.20 \mathrm{mg} \mathrm{g}^{-1}$ (Fig. 2). The highest amount of ursolic acid $\left(4.20 \pm 0.23 \mathrm{mg} \mathrm{g}^{-1}\right)$ was found in apple fruit of the 'Birutes pepinas', and this amount differed statistically significantly $(p<0.05)$ from that found in apple fruit of other cultivars. The lowest amount of ursolic acid $\left(0.20 \pm 0.06 \mathrm{mg} \mathrm{g}^{-1}\right)$ was found in apple fruit of the 'Golden Russet', and it did not differ statistically significantly $(p>0.05)$ from that detected in apple fruit of 'Danų karalienè Luiza'.

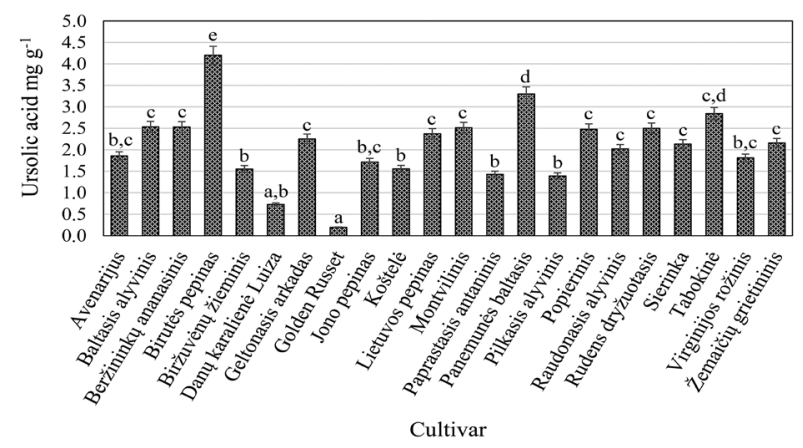

Note. The means followed by different letter are significantly different at $p<0.05$; data described as mean \pm standard deviation.

Figure 2. Variation in the quantitative amount of ursolic acid in fruit of the old apple cultivars

To evaluate the variation in the quantitative composition of triterpenic compounds between apple fruit of different cultivars, coefficients of variation indicating the range of variation of each compound were calculated. The amount of ursolic acid differed between apple fruit of the studied old Lithuanian cultivars. The coefficient of variation of the amount of ursolic acid $(60.30 \%)$ in apple fruit was higher than that in the total amount of triterpenic compounds $(\mathrm{CV}=57.63 \%)$.

In apple fruit of the studied cultivars, saponin (ursolic acid) was the predominant triterpene component. 
The results of the study conducted by Sut et al. (2019) confirm those obtained in our experiment, indicating that the ursolic acid was the most abundant compound. It has been documented that ursolic acid may comprise $70 \%$ or more of the total amount of triterpenic compounds detected in extracts of apple fruit (Poirier et al., 2018). The data of other studies (Ikeda et al., 2008; Brendolise et al., 2011; Waldbauer et al., 2016) have shown that ursolic acid protects hepatocytes and mucous membranes and has a strong anti-inflammatory, antibacterial, antiviral and glycemia-lowering effect. The amount of ursolic acid in apple fruit of the cultivars 'Aldas', 'Auksis', 'Connel Red', 'Ligol', 'Lodel' and 'Rajka' grown in Lithuanian industrial orchards ranges from $1.18 \pm 0.06$ to $2.58 \pm 0.14 \mathrm{mg} \mathrm{g}^{-1}$. The highest amount of ursolic acid $\left(2.58 \pm 0.14 \mathrm{mg} \mathrm{g}^{-1}\right)$ was found in apple fruit of the 'Lodel' and the lowest $\left(1.18 \pm 0.06 \mathrm{mg} \mathrm{g}^{-1}\right)$ - in the 'Aldas' (Butkevičiūtè et al., 2018). Apple fruit of old cultivars included in the collection of National Plant Genetic Resources were found to have higher amount of ursolic acid compared to apple fruit of the cultivars grown in Lithuanian industrial orchards.

Bars-Cortina et al. (2017) conducted a study, where they evaluated the phytochemical composition of the fruit of red-fleshed and white-fleshed apple cultivars grown in industrial orchards of Spain and the phytochemical composition of the fruit of old whitefleshed apple cultivars. The results of this study showed that the amount of ursolic acid in fruit of red-fleshed apple cultivars ranged from $1.32 \pm 0.24$ to $3.09 \pm 0.23 \mathrm{mg} \mathrm{g}^{-1}$, in fruit of white-fleshed apple cultivars - from $1.40 \pm 0.14$ to $3.26 \pm 0.42 \mathrm{mg} \mathrm{g}^{-1}$ and in fruit of old white-fleshed apple cultivars - from $1.84 \pm 0.33$ to $2.68 \pm 0.99 \mathrm{mg} \mathrm{g}^{-1}$. The results of this study showed that the amount of ursolic acid found in fruit of apple cultivars grown in industrial and private orchards of Spain was lower than that found in apples of the cultivars included into the collection of National Plant Genetic Resources.

Nour et al. (2010) and Yanrong (2016) have found that the quantitative composition of biologically active compounds varied depending on the following factors: climatic conditions, geographic latitude, soil, orchard management technologies, harvesting time and storage conditions. The results of study of Viškelis et al. (2018) established a dependence of triterpene accumulation on orchard management technologies and fruit position in tree canopy. Triterpene accumulation in apple fruit was directly correlated with crop load: a higher amount of triterpenes was found in fruit harvested from the inner canopy of the apple tree. Tree growth regulation affected the synthesis of triterpenes - trunk incision decreased the amount of total triterpenes.

A comparative analysis of the quantitative composition of apple fruit of cultivars grown in industrial orchards of Spain and Lithuania showed that in apple fruit of the old cultivars included into the collection of National Plant Genetic Resources the amount of ursolic acid was higher than that found in apple fruit of cultivars grown in Spain (Bars-Cortina et al., 2017; Butkevičiūtè et al., 2018).

The quantitative composition of oleanolic acid in apple fruit of the studied old Lithuanian cultivars ranged from $0.24 \pm 0.05$ to $0.87 \pm 0.96 \mathrm{mg} \mathrm{g}^{-1}$ (Fig. 3). The highest amount of oleanolic acid $\left(0.87 \pm 0.96 \mathrm{mg} \mathrm{g}^{-1}\right)$ was found in apple fruit of the 'Pilkasis alyvinis' and the lowest $\left(0.24 \pm 0.05 \mathrm{mg} \mathrm{g}^{-1}\right)$ - in the 'Paprastasis antaninis'. The highest amount of oleanolic acid did differ statistically significantly $(p<0.05)$, and this amount differed statistically significantly $(p<0.05)$ from that found in apple fruit of other cultivars. The detected amount of oleanolic acid varied in apple fruit of the old cultivars. The coefficient

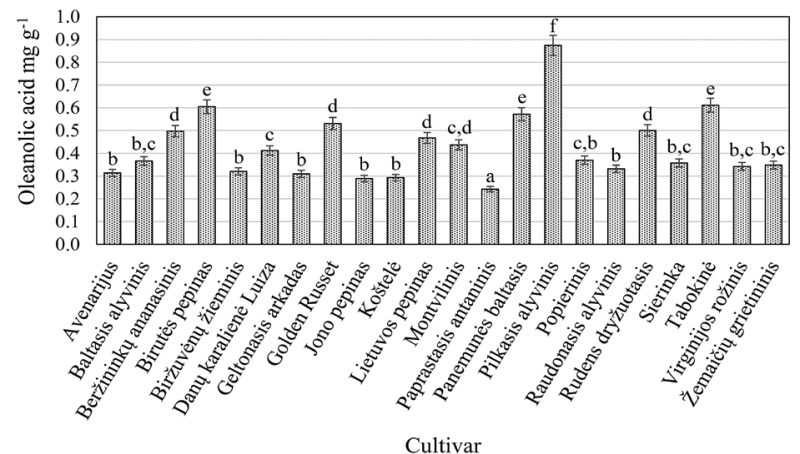

Note. The means followed by different letter are significantly different at $p<0.05$; data described as mean \pm standard deviation.

Figure 3. Variation in the quantitative amount of oleanolic acid in fruit of the old apple cultivars

of variation of the amount of oleanolic acid in apple fruit ranged from $\mathrm{CV}=0.75 \%$ to $\mathrm{CV}=80.82 \%$.

The results of our experiment showed that in apple fruit the amount of oleanolic acid was by 5.20 times lower than that of ursolic acid. Triterpenes are one of the dominant groups of compounds in cuticular wax (Buschhaus, Jetter, 2011). Oleanolic and ursolic acids are the main compounds of the wax layer of fruit and leaves (Qi et al., 2006; Koch, Ensikat, 2008), and they can be found in various fruit and berries (Peschel et al., 2007; Neto, 2011) as well as in apples (Cefarelli et al., 2006; Jäger et al., 2009). Sut et al. (2019) have found that in apple fruit of cultivars grown in industrial orchards ursolic and oleanolic acids may comprise $79-95 \%$ of the total amount of triterpenic compounds. According to the data of the study conducted by Szakiel et al. (2012), the amount of oleanolic acid in apple fruit may comprise $7-15 \%$ of the total amount of triterpenic compounds. Butkevičiūtè et al. (2018) found that in fruit of apple cultivars grown in industrial orchards of Lithuania the amount of oleanolic acid ranged from $0.32 \pm 0.02$ to 0.47 $\pm 0.11 \mathrm{mg} \mathrm{g}^{-1}$. The amount of oleanolic acid found in apple fruit of old cultivars was higher than that detected in apple fruit grown in Lithuanian industrial orchards. The amount of oleanolic acid in fruit of apple cultivars grown in industrial orchards of France and Germany ranged

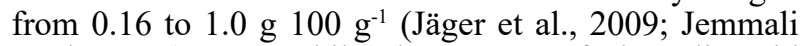
et al., 2016). Meanwhile, the amount of oleanolic acid in fruit of old apple cultivars grown in private orchards of Spain ranged from $0.71 \pm 0.13$ to $0.93 \pm 0.38 \mathrm{mg} \mathrm{g}^{-1}$ (Bars-Cortina et al., 2017). The amount of oleanolic acid detected in apple fruit of old cultivars grown in Lithuania is in line with that reported in the studies published by French, German and Spanish researchers.

The quantitative composition of corosolic acid in apple fruit of studied old Lithuanian cultivars ranged from $0.02 \pm 0.004$ to $0.41 \pm 0.04 \mathrm{mg} \mathrm{g}^{-1}$ (Fig. 4). The highest amount of corosolic acid $\left(0.41 \pm 0.04 \mathrm{mg} \mathrm{g}^{-1}\right)$ was detected in apple fruit of the 'Raudonasis alyvinis', but no statistically significant difference $(p>0.05)$ was found in the amount of this acid among the 'Panemunès baltasis' or 'Pilkasis alyvinis'. The lowest amount of corosolic acid $\left(0.02 \pm 0.004 \mathrm{mg} \mathrm{g}^{-1}\right)$ was detected in apple fruit of the 'Golden Russet', and this amount did not differ statistically significantly $(p>0.05)$ from that found in 'Avenarijus' or 'Virginijos rožinis'. The coefficient of variation of the amount of corosolic acid (34.48\%) in apple fruit was lower than that in the total amount of triterpenic compounds $(\mathrm{CV}=57.63 \%)$.

The results of our experiment showed that the amount of corosolic acid was by 12.12 times lower 


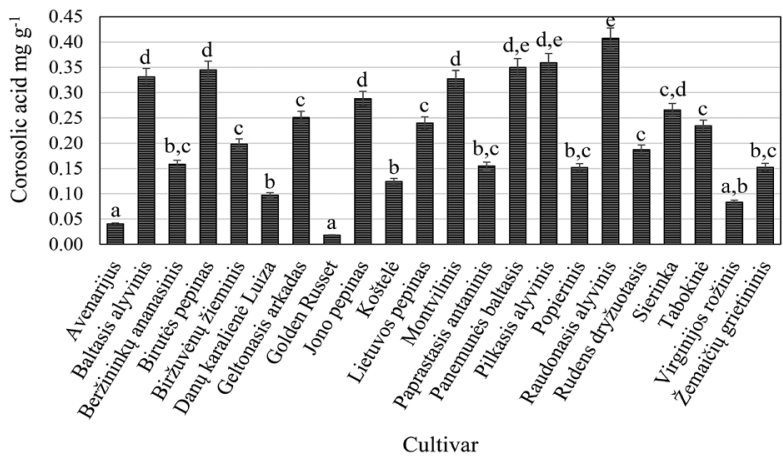

Note. The means followed by different letter are significantly different at $p<0.05$; data described as mean \pm standard deviation.

Figure 4. Variation in the quantitative amount of corosolic acid in fruit of the old apple cultivars

than that of ursolic acid and by 3.60 times lower than that of oleanolic acid. The amount of corosolic acid in fruit of apple cultivars grown in industrial orchards under Lithuanian climatic conditions ranges from 0.06 \pm 0.01 to $0.27 \pm 0.08 \mathrm{mg} \mathrm{g}^{-1}$ (Butkevičiūtè et al., 2018). The amount of corosolic acid found in apple fruit of old cultivars was higher than that found in apple fruit grown in industrial orchards of Lithuania. Jäger et al. (2009) published results, indicating that the highest amount of corosolic acid in apple fruit was $0.51 \mathrm{~g} 100 \mathrm{~g}^{-1}$. The amount of corosolic acid detected in our experiment confirm the results published by the afore mentioned German researchers.

The amount of betulinic acid detected in fruit of old apple cultivars grown in Lithuania was the lowest of all the identified and quantitatively evaluated triterpenic compounds. The results of our experiment did not reveal any statistically significant difference $(p>0.05)$ in the amount of betulinic acid between apple fruit of the studied old Lithuanian cultivars (Fig. 5). The highest amount of betulinic acid $\left(0.03 \pm 0.008 \mathrm{mg} \mathrm{g}^{-1}\right)$ was found in apple fruit of the 'Tabokine', and the lowest amounts $(0.01 \pm$ $0.001 \mathrm{mg} \mathrm{g}^{-1}$ ) were detected in 'Avenarijus', 'Biržuvènų žieminis', 'Geltonasis arkadas', 'Jono pepinas', 'Pilkasis alyvinis', 'Raudonasis alyvinis', 'Virginijos rožinis' and 'Žemaičiu grietininis'. The coefficient of variation of the amount of betulinic acid $(58.03 \%)$ in apple fruit was higher than that in the total amount of triterpenic compounds $(\mathrm{CV}=57.63 \%)$.

The amount of betulinic acid detected in fruit of apple cultivars grown in industrial orchards of Lithuania ranged from $0.02 \pm 0.005$ to $0.03 \pm 0.005 \mathrm{mg} \mathrm{g}^{-1}$ (Butkevičiūtè et al., 2018). The amount of betulinic

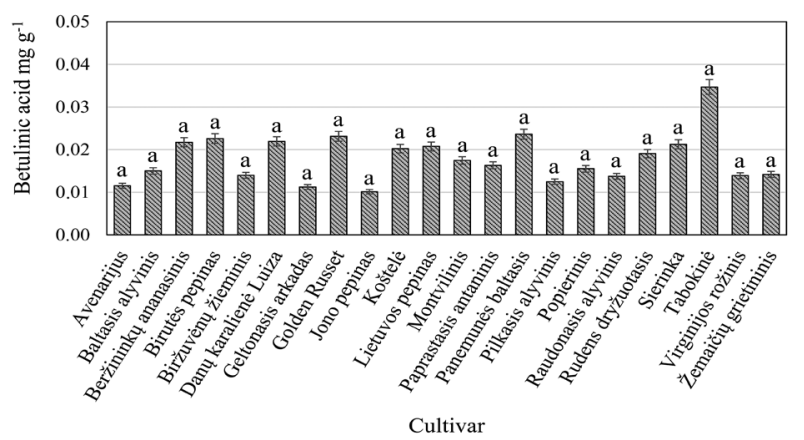

Note. The means followed by different letter are significantly different at $p<0.05$; data described as mean \pm standard deviation.

Figure 5. Variation in the quantitative amount of betulinic acid in fruit of the old apple cultivars acid found in apple fruit of cultivars grown in industrial orchards under Lithuanian climatic conditions did not differ from that detected in apple fruit of the cultivars included in the collection of National Plant Genetic Resources. Bars-Cortina et al. (2017) found that the variation in the amount of betulinic acid in apple fruit of old cultivars reached $0.24 \pm 0.08 \mathrm{mg} \mathrm{g}^{-1}$. The evaluation of the qualitative and quantitative composition of apple fruit of cultivars included in the collection of National Plant Genetic Resources showed that the amount of betulinic acid did not differ from that found in apple fruit of cultivars grown in industrial orchards in Lithuania. However, it was higher than that detected in apple fruit of old cultivars grown in orchards in Spain.

Currently, there are ongoing discussions on the application of health-enhancing food in medical practice, i.e. the prevention of various diseases. The nutritional value of the fruit of apple cultivars included in the collection of National Plant Genetic Resources is equal to that of the fruit of cultivars grown in industrial orchards. For this reason, detailed studies of the chemical composition of biologically active compounds in apples of the old cultivars are relevant. Such studies would allow for offering the consumers high-quality apples and apple products with a known composition of triterpenic compounds, which could be potentially valuable for medical purposes and creation and manufacturing of functional food.

The results of our experiment showed that the total amount of triterpenic compounds in apple fruit of old Lithuanian cultivars ranged from $0.77 \pm 0.38$ to $5.17 \pm 0.86 \mathrm{mg} \mathrm{g}^{-1}$ (Fig. 6). The highest total amount of triterpenic compounds $\left(5.17 \pm 0.86 \mathrm{mg} \mathrm{g}^{-1}\right)$ was detected in apple fruit of the 'Birutès pepinas', and this amount differed statistically significantly $(p<0.05)$ from that found in apple fruit of other cultivars. The lowest total amount of triterpenic compounds $\left(0.77 \pm 0.38 \mathrm{mg} \mathrm{g}^{-1}\right)$ was detected in apple fruit of the 'Golden Russet', and it did not differ statistically significantly $(p>0.05)$ from that found in 'Danu karalienè Luiza' or 'Paprastasis antaninis'.

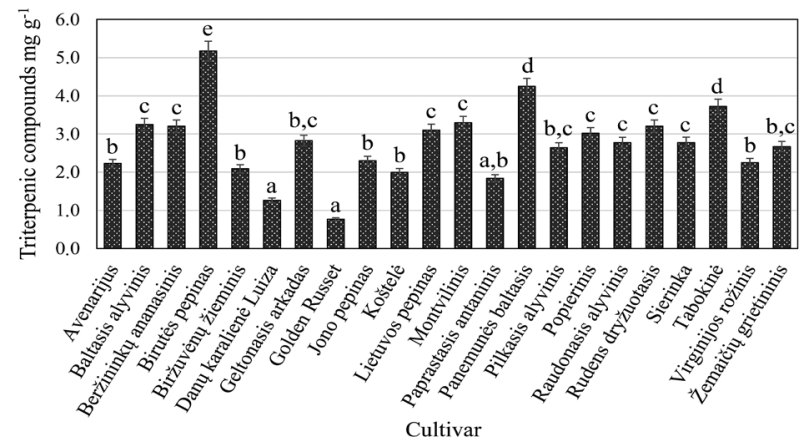

Note. The means followed by different letter are significantly different at $p<0.05$; data described as mean \pm standard deviation.

Figure 6. Variation in the total amount of triterpenic compounds in fruit of the old apple cultivars

The genetic background of apple cultivars is the main factor in the accumulation of triterpenes in fruit. Numerous studies have reported cultivar differences in triterpene concentration. He and Liu (2007) identified 13 triterpenoids in 'Red Delicious' apples, and McGhie et al. (2011) identified 43 compounds in the fruit of 7 tested apple cultivars and found that the 'Fuji' had the highest total amount, while the 'Granny Smith' had the lowest.

The total amount of triterpenic compounds in 'Aldas', 'Auksis', 'Connel Red', 'Ligol', 'Lodel' and 'Rajka' apples grown in Lithuanian industrial orchards ranged from $1.64 \pm 0.07$ to $3.17 \pm 0.14 \mathrm{mg} \mathrm{g}^{-1}$. The 
highest total amount of triterpenic compounds $(3.17 \pm$ $0.14 \mathrm{mg} \mathrm{g}^{-1}$ ) was found in apple fruit of the 'Lodel' and the lowest $\left(1.64 \pm 0.07 \mathrm{mg} \mathrm{g}^{-1}\right)$ - in the 'Aldas' (Butkevičiùtè et al., 2018). The amount of triterpenic compounds found in fruit of apple trees grown in Lithuanian industrial orchards was lower than that detected in apple fruit of old cultivars included in the collection of National Plant Genetic Resources. The total amount of triterpenic compounds found in apple fruit of old cultivars grown in Polish orchards ranged from 0.47 to $3.75 \mathrm{mg} \mathrm{g}^{-1}$ (Oszmiański et al., 2018) and was lower than that found during our experiment.

Some studies (Smania et al., 2003; Kumar et al., 2007; Yuan et al., 2009) showed that triterpene compounds have antifungal activity and can play a role in plant defence against diseases. Poirier et al. (2018) established that triterpene accumulation in apple peal can be related to superficial scald, a postharvest apple browning disorder. Triterpenes accumulated in the wax layer act as a protection against biotic stresses and can enhance post-harvest quality of the fruit (Lara et al., 2014). Studies with persimmon fruit (Tsubaki et al., 2013) demonstrated that triterpenoids might increase the mechanical resistance of the cuticle and protect against water loss. The difference in triterpene concentration among the tested cultivars can be associated with the resistance of fruit to various diseases.

To evaluate the variation in the quantitative composition of triterpenic compounds between apple fruit of the studied old Lithuanian cultivars, coefficients of variation, which showed the range of the variation in the total amount of triterpenic compounds, were calculated. The coefficient of variation of the total amount of triterpenic compounds ranged from $3.90 \%$ to $57.63 \%$ (Table).

Following the hierarchical cluster analysis, the apple fruit of the studied old Lithuanian cultivars were distributed into four clusters (Fig. 7A). Apple fruit assigned to cluster I contained moderate total amount of triterpenic compounds (from $1.84 \pm 0.41$ to $3.30 \pm 0.69 \mathrm{mg} \mathrm{g}^{-1}$ ). Cluster II included the 'Birutès pepinas', whose fruit was found to contain the highest total amount of triterpenic compounds $\left(5.17 \pm 0.86 \mathrm{mg} \mathrm{g}^{-1}\right)$. Apple fruit of 'Golden Russet' and 'Danų karalienè Luiza' assigned to cluster III had lower than moderate total amount of triterpenic compounds (from $0.77 \pm 0.38$ to $1.26 \pm 0.49 \mathrm{mg} \mathrm{g}^{-1}$ ). Apple fruit of 'Panemunès baltasis' and 'Tabokiné' assigned to cluster IV was found to have higher than moderate total amount of triterpenic compounds (from $3.72 \pm 0.57$ to $4.25 \pm 0.17 \mathrm{mg} \mathrm{g}^{-1}$ ) (Fig. 7A).

The PCA of triterpenic compounds found in apple fruit included in the collection of National Plant Genetic Resources was conducted. Two principal components that explain $75.89 \%$ of the overall dispersion of the studied data were used for the detailed analysis (Fig. 7B). The amount

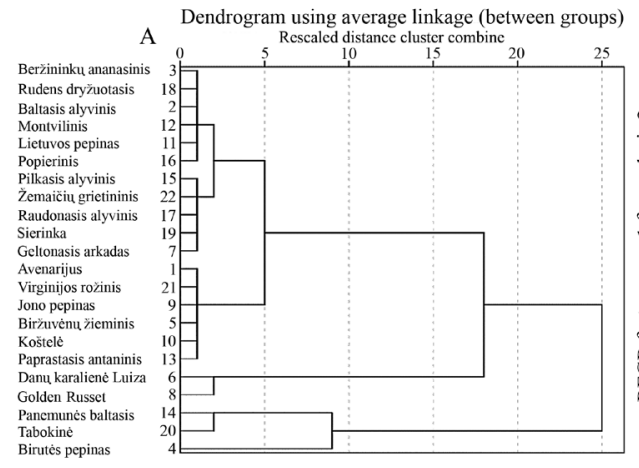

of ursolic acid very strongly positively $(0.875)$ correlated with the first component, which described $54.60 \%$ of the overall data dispersion. The correlation of the amount of corosolic acid with this component was very strong as well (0.846). A very strong positive $(0.922)$ correlation was found between the amount of betulinic acid and the second component, which described $21.29 \%$ of the overall data dispersion, while the correlation of the amount of oleanolic acid with this component was moderately strongly positive (0.578).

Around the world, a selection of local cultivars is performed with the aim of creating new or improving the existing fruit tree cultivars. The appearance of the apples of the old cultivars does not meet the commercial standards set for apples grown in industrial orchards. Besides, the fruit is usually smaller, its shape is irregular and has thick leathery skin. Despite the aforementioned differences, the interest in the fruit of old apple tree cultivars is continually growing (Lo Piccolo et al., 2019). Apple trees of old cultivars growing or grown in local neighbourhoods are gaining popularity, their fruit contains higher amount of biologically active compounds, and the trees are more resistant to diseases and better adapted to climatic conditions, thus capable of ripening fruit within a short vegetation period (Sut et al., 2019). Apple fruit of cultivars included in the collection of National Plant Genetic Resources were found to have higher total amount of triterpenic compounds compared to apples grown in Lithuanian industrial orchards. According to experimental data, apple fruit grown in private orchards of Poland and Italy had lower total amount of triterpenic compounds, compared to apple fruit of old cultivars grown under Lithuanian climatic conditions.

The obtained results provided new knowledge about the apple cultivars included in the collection of National Plant Genetic Resources and about the variation in the qualitative and quantitative composition of triterpenic compounds in their fruit.

The old apple cultivars 'Golden Russet', 'Beržininkų ananasinis', 'Biržuvènų žieminis', 'Danų karalienė Luiza', 'Jono pepinas', 'Koštelè', 'Montvilinis' and 'Panemunès baltasis' grown in Lithuania are scabresistant (Table). The highest total amount of triterpenic compounds were found in apple fruit of scab-resistant cultivars 'Panemunès baltasis' and 'Tabokine' and in the 'Birutès pepinas', which is susceptible to scab. The fruit of the 'Panemunès baltasis' have a waxy skin. Apple fruit of the scab-resistant cultivars 'Golden Russet' and 'Danu karaliene Luiza' was found to have the lowest amount of triterpenic compounds. The fruit skin is covered with a rust grid.

The results of the current study suggest that the resistance of the 'Panemunès baltasis' and 'Tabokine' to scab is due to a combination of factors, including the

\section{B}

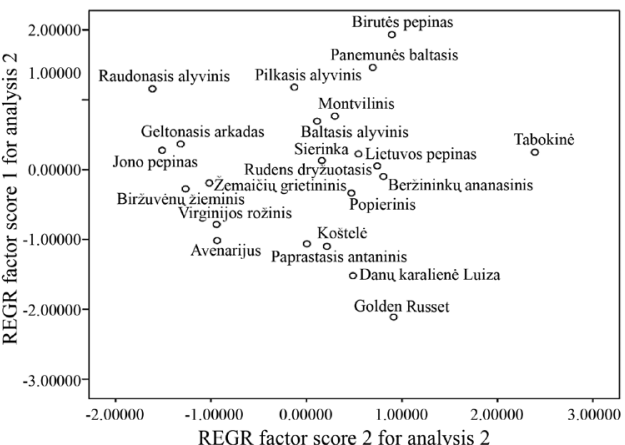

Figure 7. A dendrogram of similarities between apple fruit with respect to the total amount of triterpenic compounds (A) and PCA of triterpenic compounds in apple fruit (B) 
effect of polygenes on scab resistance and the antifungal effect of triterpenic compounds, which depends on the composition of triterpenic compounds, their combinations and amount ratios. The resistance of the 'Golden Russet' and 'Danu karalienè Luiza' is due to genetic factors, i.e. scab resistance genes. A high total amount of the studied triterpenic compounds in the fruit of the 'Birutes pepinas' does not protect it from scab. This supports the finding that resistance genes are the main factor in apple resistance to scab (Annu et al., 2019). The fruit of the old apple cultivars 'Panemunès baltasis' and 'Tabokinè' grown in collection of National Plant Genetic Resources is a promising option for ecological harvesting and isolation of triterpenic compounds with a versatile and significant effect on human health.

\section{Conclusions}

1. A variation in the qualitative and quantitative composition of triterpenic compounds was found in the apple fruit of old Lithuanian cultivars included in the collection of National Plant Genetic Resources. The highest total amount of triterpenic compounds $\left(5.17 \pm 0.86 \mathrm{mg} \mathrm{g}^{-1}\right)$ was found in the 'Birutès pepinas'; higher total amounts were also found in 'Tabokinè' and 'Panemunès baltasis' (3.72 \pm 0.57 and $4.25 \pm 0.17 \mathrm{mg} \mathrm{g}^{-1}$, respectively).

2. The following triterpenic compounds: betulinic acid, corosolic acid, oleanolic acid and ursolic acid, were identified and quantified in apple fruit of old cultivars. By their quantitative composition triterpenic compounds in apple fruit may be listed in the following order: ursolic acid $>$ oleanolic acid $>$ corosolic acid $>$ betulinic acid. Among the apple fruit of the studied cultivars, ursolic acid was the predominant triterpenic compound. Its highest amount $\left(4.20 \pm 0.23 \mathrm{mg} \mathrm{g}^{-1}\right)$ was found in apple fruit of the 'Birutès pepinas'. The results of our experiment showed that the amount of oleanolic acid in apple fruit was by 5.20 times, and the amount of corosolic acid - by as many as 12.12 times lower than that of ursolic acid. The highest amount of oleanolic acid $(0.87$ $\pm 0.96 \mathrm{mg} \mathrm{g}^{-1}$ ) was found in apple fruit of the 'Pilkasis alyvinis', and the highest amount of corosolic acid (0.41 $\left.\pm 0.04 \mathrm{mg} \mathrm{g}^{-1}\right)$ - in the 'Raudonasis alyvinis'. The amount of betulinic acid was the lowest of all the qualitatively and quantitatively evaluated triterpenic compounds.

3. The old apple cultivars 'Birutès pepinas', 'Panemunès baltasis' and 'Tabokine' included in the collection of National Plant Genetic Resources have a potential for cultivation in industrial orchards and for the use of their apples and processed apple products as natural functional foods rich in triterpenic compounds and adapted for medical purposes, including the prevention of various diseases.

\section{Acknowledgments}

This research was partly supported by the project No. LLI-181 Heritage Gardens of the Interreg V-A Latvia-Lithuania program 2014-2020.

Received 20052020

Accepted 02102020

\section{References}

Allouche Y., Beltrán G., Gaforio J. J., Uceda M., Mesa M. D. 2010. Antioxidant and antiatherogenic activities of pentacyclic triterpenic diols and acids. Food and Chemical Toxicology, $48 \cdot ? 885-2800$ https://doi.org/10.1016/j.fct.2010.07.022

Annu, Kani K., Sharma J. K. 2019. Studies on biology and management of apple scab incited by Venturia inaequalis. Review article. International Journal of Current Microhinlngy and Annlied Sciences, 8 (1): 162-182. https://doi.org/10.20546/ijcmas.2019.801.019
Bars-Cortina D., Macià A., Iglesias I., Romero M. P., Motilva M. J. 2017. Phytochemical profiles of new redfleshed apple varieties compared with traditional and new white-fleshed varieties. Journal of Agricultural and Food Chemistry $65(8): 1684-06$ https://doi.org/10.1021/acs.jafc.6b02931

Biviliene À., Baliuckiene A., B̄iažyte A., Dapkūnienè S., Sveistytè L. 2010. Lietuvos augalu nacionaliniai genetiniai ištekliai (ex situ). Lietuvos Respublikos aplinkos ministerija, Augalu genu bankas, 74 p. (in Lithuanian).

Blažytè A. 2008. Lietuvos augalu nacionaliniai genetiniai ištekliai. Senosios lietuviškos vaismedžių veislès. Lietuvos Respublikos aplinkos ministerija, Augalu genu bankas, 25 p. (in Lithuanian)

Brendolise C., Yauk Y.-K., Eberhard E. D., Wang M., Chagne D., Andre C., Greenwood D. R., Beuning L. L. 2011. An unusual plant triterpene synthase with predominant $\alpha$-amyrin producing activity identified by characterizing oxidosqualene cyclases from Malus domestica. The FEBS Inurna1, 278 (14): 2485-2400 https://doi.org/10.1111/j.1742-4658.2011.08175.x

Buschhaus C. Jetter K. 2U11. Composition difterences between epicuticular and intracuticular wax substructures: how do plants seal their epidermal surfaces? Journal of experimental botany 62 (3): 841-853. https://doi.org/10.1093/jxb/erq366

Butkeviciute A., Liaudanskas M., Kviklys D., ZymonėZ., Raudonis R., Viškelis J., Uselis N., Janulis V. 2018. Detection and analysis of triterpenic compounds in apple extracts. International Journal of Food Properties, 21:1716-1727 https://doi.org/10.1080/10942912.2018.1506478

Cefarelíi G., $\bar{D}$ 'Abrosca $\bar{B}$., Fiorentino A., Izzo A., Mastellone C., Pacifico S. Piscopo V. 2006. Freeradical-scavenging and antioxidant activities of secondary metabolites from reddened cv. Annurca apple fruits. Journal of A rricultural and Fond Chemistry, 54 (3): 803-809. https://doi.org/10.1021/jf052632g

Contessa C., Botta K. 2016. Comparison of physicochemical traits of red-fleshed, commercial and ancient apple cultivars. Horticultural Science, 43: 159-66. https://doi.org/10.17221/132/2015-HORTSCI

De Yaepe ע., Valkenborg D., Noten B., Servaes K., Diels L., De Loose M. 2015. Variability of the phenolic profiles in the fruits from old, recent and new apple cultivars cultivated in Reloium Metaholomirs 11 (3). 730_75) https://doi.org/10.1007/s11306-014-0730-2

Grigoras C. G., Destandau E., Fougere L., Elfakir C. 2013. Evaluation of apple pomace extracts as a source of bioactive compounds. Industrial Crops and Products, 49: 794-804. https://doi.org/10.1016/j.indcrop.2013.06.026

He X., Liu K. H. 200\%. Iriterpenoids isolated from apple peels have potent antiproliferative activity and may be partially responsible for apple's anticancer activity. Journal of A gricultural and Fond Chemistry, 55 (11): 4366-4370. https://doi.org/10.1021/jf0635630

Ikeda Y., Murakami A., Uhigashi H. 2008. Ursolic acid: an antiand proinflammatory triterpenoid. Molecular Nutrition Fond Research, 52: 26-42 https://doi.org/10.1002/mnfr.200700389

Jäger S Irojan H., Kopp I., Laszczyk M. N. Scheffler A. 2009. Pentacyclic triterpene distribution in various plants rich sources for a new group of multi potent plant extracts. Molecules $14: 2016-2031$. https://doi.org/10.3390/molecules 14062016

Jemmali Z., Chartiern A., Dufresne C., Eltakir C. 2016. Optimization of the derivatization protocol of pentacyclic triterpenes prior to their gas chromatography - mass snectrometry analysic in nlant extracts. Talanta, 147: 35-43. https://doi.org/10.1016/j.talanta.2015.09.026

Jeong J. W., Shim J. J., Choi I. D., Kim S. H., Ka J., Ku H. K., Lee D. E., Kim T. Y. Jeung W. Lee J. H., Lee K. W., Huh C. S., Sim J. H., Ahn Y.T. 2015. Apple pomace extract improves endurance in exercise performance by increasing strength and weight of skeletal muscle. Journal of Medicinal Fond $18(12): 1380-1386$ https://doi.org/10.1089/jmf.2014.3401

Koch K., Ensikat H. J. 2008. The hydrophobic coatings of plant surfaces: epicuticular wax crystals and their morphologies, crystallinity and molecular self-assembly. Micron, 30 (7): 750-772. https://doi.org/10.1016/j.micron.2007.11.010

Kumar K., Chaturvedi A. K., Shukia P. K., Lakshmi V. 2007. Antifungal activity in triterpene glycosides from the sea cucumber Actinopyga lecanora. Bioorganic and Medicinal cucumber Actinopyga lecanora. Bioorg
Chemictry I etters, 17 (15): 4387-4391. https://doi.org/10.1016/j.bmcl.2006.12.052 
Kviklys D., Gelvonauskienė D., Karklelienė R., JuškevičienėD., Dambrauskienė E., Uselis N., Lanauskas J., Ikase L., Lepse L., Kaufmane E., Feldmane D., Dēķena Dz., Zeipina S. 2020. Paveldo sodai. Veislių katalogas, p. 31-83 (in Lithuanian).

Lara I., Belge B., Goulao L.F. 2014. The fruit cuticle as a modulator of postharvest quality. Review. Postharvest Biolngy and Technolngy, 87: 103-112 https://doi.org/10.1016/j.postharvbio.2013.08.012

Lo Piccolo E., Landi M., Massai R., Remorini D., Conte G., Guidi L. 2019. Ancient apple cultivars from Garfagnana (Tuscany, Italy): a potential source for 'nutrafruit' production. Fond Chemistry. 294: 518-25. https://doi.org/10.1016/j.foodchem.2019.05.027

McGhie T. K., Hudault S., Lunken R. C., Christeller J. T. 2011. Apple peels, from seven cultivars, have lipase-inhibitory activity and contain numerous ursenoic acids as identified by LC-ESI-QTOF-HRMS. Journal of Agricultural and Fond Rhemistry 60 (1) $487-491$. https://doi.org/10.1021/jf203970j

Neto C.C.2011. Ursolic acid and other pentacyclic triterpenoids: anticancer activities and occurrence in berries. Seeram N., Stoner G. (eds). Berries and Cancer Prevention. Springer, n. $41-49$. https://doi.org/10.3390/molecules24152751

Nour V., Trandafir I., Ionica M. E. 2010. Compositional characteristics of fruits of several apple (Malus domestica Borkh.) cultivars. Notulae Botanicae Horti Agrobotanici Clui-Nanoca. 38 (3): 228-233.

https://doi.org/10.15835/nbha3834762

Oszmiański J., Lachowicz S., Gławdel E., Cebulak T. Ochmian I. 2018. Determination of phytochemical composition and antioxidant capacity of 22 old apple cultivars grown in Poland. European Food Research and Technolnov $744(4) \cdot 647-6$ ? https://doi.org/10.3390/molecules22050853

Padua 'T. A., Abreu B. S. S. C., Costa T. E. M. M., Nakamura M. J., Valente L. M. M., Henriques M. G., Siani A. C., Rosas E. C. 2014. Anti-inflammatory effects of methyl ursolate obtained from a chemically derived crude extract of apple peels: potential use in rheumatoid arthritis. Archives of Pharmacal Research, 37 (11) 1 1487-1495. https://doi.org/10.3390/molecules22030400

Peschel S., Franke R., Schreiber L., Knoche M. 2007. Composition of the cuticle of developing sweet cherry fruit Phytochemistry 68 (7) $1017-1025$ https://doi.org/10.1016/j.phýtochem.2007.01.008
Poirier B. C., Buchanan D. A., Mattheis J., Rudell D. 2018. Differential partitioning of triterpenes and triterpene esters in apple peel. Journal of Agricultural and Food Chemistry, $66(8): 1800-1806$

https://doi.org/10.1021/acs.jafc. 7b04509

Qi S., Ding L., Tian K., Chen X., Hu Z. 2006. Novel and simple nonaqueous capillary electrophoresis separation and determination bioactive triterpenes in Chinese herbs. Journal of Pharmaceutical and Biomedical Analysis, 40 (1): 35-41. https://doi.org/10.1016/j.jpba.2005.06.003

Smania E. F. A., Delle Monache F., Smania A., Yunes R.A., Cuneo R. S. 2003. Antifungal activity of sterols and triterpenes isolated from Ganoderma annulare. Fitoterapia, 74 (4): $375-377$. https://doi.org/10.1016/S0367-326X(03)00064-9

Sut S., 'Zengin G., Maggi F., Malagoli M., Dall' Acqua S. 2019. Triterpene acid and phenolics from ancient apples of Friuli Venezia Giulia as nutraceutical ingredients: LC-MS study and in vitro activities Molecules, 74 (6) 1109. https://doi.org/10.3390/molecules24061́109

Szakiel A., Paczkowski C., Pensec F., Bertsch C. 2012. Fruit cuticular waxes as a source of biologically active triternennids Phytochemistry Reviews 11 (2-3): 263-28. https://doi.org/10.1007/s11101-012-9241-9

Tsubaki S., Sugimura K., 'Teramoto Y., Yonemori K., Azuma J. 2013. Cuticular membrane of Fuyu persimmon fruit is strengthened by triterpenoid nano-fillers. PLoS ONE, 8 (9): e75275 https://doi.org/10.1371/journal.pone.0075275

Viškelis J., Uselis N., Liaudanskas M., Janulis V., Bielicki P., Univer T., Lepsis J., Kviklys D. 2018. Triterpenic acid content in the fruit peel of Malus $\times$ domestica Borkh. depends on the growing technology. 7emdirhyste-Agriculture, 105(1): 71-78. https://doi.org/10.13080/z-a.2018.105.010

Waldbauer K., Seiringer G., Nguyen D. L., Winkler J., Blaschke M., McKinnon R., Urban E., Ladurner A., Dirsch V. M., Zehl M., Kopp B. 2016. Triterpenoic acids from apple pomace enhance the activity of the endothelial nitric oxide synthase (eNOS). Journal of Agricultural and Fond Chemistry. 64: 185-194. https://doi.org/10.1021/acs.jafc.5b05061

Yanrong L. 2016. Iriterpenes and phenolic compounds in apple fruit (Malus domestica Borkh.): doctoral thesis. Acta Universitatis Agriculturae Sueciae, 5: 13-24.

Yuan W. H., Yi Y. H., Tang H. F., Liu B. S., Wang Z. L., Sun G. Q., Zhang W., Li L., Sun P. 2009. Antifungal triterpene glycosides from the sea cucumber Bohadschia marmorata. Planta Medica. 75 (2): 168-173. https://doi.org/10.1055/s-0028-1088348

\title{
Lietuvos senųjų obels veislių vaisių triterpeninių junginių kokybinė ir kiekybinè sudètis
}

\author{
A. Butkevičiūtė ${ }^{1}$, M. Liaudanskas ${ }^{1,2}$, D. Kviklys ${ }^{2,3}$, D. Gelvonauskienè $\dot{2}^{2}$, V. Janulis ${ }^{1}$ \\ ${ }^{1}$ Lietuvos sveikatos mokslų universiteto Medicinos akademija \\ ${ }^{2}$ Lietuvos agrarinių ir miškų mokslų centro Sodininkystès ir daržininkystès institutas \\ ${ }^{3}$ Norvegijos bioekonomikos tyrimų institutas
}

\section{Santrauka}

Pasaulyje didèja susidomėjimas senųų veislių obelimis, jų vaisiais ir perdirbtais produktais. Biologiškai aktyvių junginiu kokybinès ir kiekinès sudèties tyrimai yra svarbūs vertinant obuoliu kokybę ir jų mitybines savybes. Taikant efektyviosios skysčių chromatografijos metodą Augalų nacionalinių genetinių išteklių kolekcijai priskirtų obels veislių obuolių ėminiuose nustatyta triterpeninių junginių kokybinė ir kiekinè sudètis. Didžiausias suminis triterpeninių junginių kiekis $\left(5,17 \pm 0,86 \mathrm{mg} \mathrm{g}^{-1}\right)$ nustatytas veislès 'Birutès pepinas' obuolių èminiuose. Didesni suminiai triterpeninių junginių kiekiai $\left(3,72 \pm 0,57\right.$ ir 4,25 $\left.\pm 0,17 \mathrm{mg} \mathrm{g}^{-1}\right)$ nustatyti veislių 'Tabokinè' ir 'Panemunès baltasis' obuolių ėminiuose. Pagal kiekinę sudèti obuolių ėminiuose triterpeniniai junginiai pasiskirste taip: ursolio rūgštis $>$ oleanolio rūgštis $>$ korosolio rūgštis $>$ betulino rūgštis.

Augalų nacionalinių genetinių išteklių kolekcijai priskirtos senosios veislès 'Birutès pepinas', 'Panemunès baltasis' ir 'Tabokinè' obelys yra perspektyvios auginti pramoniniuose soduose, obuolius bei jų perdirbimo produktus vartoti kaip natūralų, daug triterpeninių junginių turintị funkcinị maistą, taikomą medicinos srityje ligų prevencijai.

Reikšminiai žodžiai: obuoliai, senosios veislès, triterpeniniai junginiai. 